\title{
Coalition Projects to Cut Back Costs of Cleaning Recreational Water Bodies: The Case of Lake Rozkoš
}

\author{
Petr Šauer*, Petr Fiala, Antonín Dvořák, Ondřej Kolínský \\ University of Economics, Prague, W. Churchilla 4, 13067 Prague 3, Czech Republic
}

Received: 9 November 2016

Accepted: 8 February 2017

\begin{abstract}
This paper presents the application of an optimization model developed for Lake Rozkoš, which is located in a sub-basin of the Elbe River basin in Bohemia. Two scenarios for achieving environmental targets (required status of the lake water) were formulated by specialists, together with an assessment of the investment and operating costs of the projects. The optimal solution (investment program) for 41 pollutermunicipalities, where 166 coalitions can be considered (41 individual and 125 joint wastewater treatment plants), was computed. The results suggest that the modelling method presented in this paper has the potential to increase the role of economic considerations in the early stages of planning and decision-making about water treatment programs. In this case, more than $20 \%$ of the costs could be saved when selected joint wastewater treatment plants are realized. The approach has the potential to contribute to increasing costeffectiveness of allocation of financial sources from national and European Union sources.
\end{abstract}

Keywords: water pollution, abatement costs, cost-effectiveness, optimization, reverse combinatorial auctions

\section{Introduction}

Until recently, in order to treat polluted fresh water it has been typical for major polluters to be addressed from larger to smaller and from springs to river estuaries. The implementation of Water Directive 2000/60/EC [1] contributed significantly to solving water pollution problems in the past.

The impacts of climate change on water regimes increased living standards and decreased surface water pollution caused by larger and medium-sized polluters have led to a new strategy: the focus is now on the

*e-mail: sauer@vse.cz protection of relatively small areas such as drinking water reservoirs, recreational lakes, and parts of watersheds where there is an increased demand for special protection of nature [2-3].

The difference from the previous situation is that multiple (rather smaller) polluters that should be addressed to achieve environmental targets are located in relatively small territories. In this situation, it might make sense for polluters to create coalitions and collaborate on common treatment projects (for instance, building common water treatment plants) in order to save on costs of achieving environmental targets.

In our paper, we focus on cases in which, in order to achieve the target, all polluters must contribute to certain projects to reduce pollution, which could be an 
individual project or a common project for two or more polluters. Significant (i.e., almost zero) phosphorus emission reduction to avoid algae and blue-green algae (Cyanobacteria) in recreational and drinking water reservoirs are typical cases of such scenarios.

Alternative approaches could be used for calculating the optimal (cost-effective) solution in complex situations, when a large number of possible coalitions do exist and it is difficult to find the optimal solution intuitively. Optimization methods can be used to find cost-effective solutions for the constraints of ecological conditions. Multi-objective optimization methods can help find solutions for a number of criteria [4].

The problem of water quality and quantity management has been approached in theoretical works for decades. Among the fundamental works is a paper by Revelle et al. [5] that applies linear programming to the problem of maximizing pollution abatement under budgetary constraints. Later, Lee and Wen [6] performed multiobjective optimization involving vague and imprecise information, and more recently, Huang and Loucks [7] used stochastic programming to simulate uncertainty. While the perspective taken in this paper is similar to that in older works, it is novel in its focus. Here, optimization will be performed with regard to the number of plants and their distribution in the area. This problem has not been previously tackled, as it seemed trivial that plants should be located in the major municipalities in the region and that surrounding villages could be connected to these areas. In the case of Lake Rozkoš, however, we show that the solution is far from obvious and that substantial savings are possible with this optimization approach.

In our paper, we apply the reverse combinatorial auction theory [8-10]. Compared with the other optimization methods/approaches mentioned above, it offers a good theoretical framework for further investigating the behaviour of the subject-polluter when creating coalitions.

The paper is structured as follows: the second section describes the situation at recreational Lake Rozkoš in eastern Bohemia (the Czech Republic), the methodology of finding cost-effective solutions is presented in the third section, and the final parts of the paper discuss the results of the calculations together with the sensitivity analysis results.

\section{Experimental}

\section{Lake Rozkoš: a Brief Description of the Case Study}

Lake Rozkoš is located in northeastern Bohemia, about $30 \mathrm{~km}$ east of the regional city of Hradec Králové. Its watershed covers a total area of $460 \mathrm{~km}^{2}$ and consists of two parts, with the main and more important one being a part of the watershed of the Úpa River. Several smaller streams, especially Rovenský and Šonovský brooks, also contribute to the lake's waters. Thirty-four municipalities and 75 small settlements are located in the basin with about
82,000 permanent inhabitants (see Fig. 1 for the watershed area). The lake is divided into two parts, northern and southern, and covers a total area of 1,000 hectares.

The Lake Rozkoš project was finalised in 1972 by bringing the main source of water from the Úpa River via a feeder channel. Its main functions are as follows [11-13]: transfer of water from the Úpa, accumulation of water in the reservoir, and use for compensatory increases of flow rates of the Elbe River (securing a minimum flow rate downstream of the Opatovice weir, providing a secure source of water demand for the Opatovice power plant, transferring water through the Opatovice canal), flow subsidy for the Rozkošský brook downstream of the reservoir to secure its minimum flow and water consumption for irrigation. Another major purpose was to protect parts of the town of Česká Skalice and other municipalities from floods. Fishery and sports fishing in the reservoir are additional important functions. The opportunity to swim in good-quality water is becoming increasingly important with the development of highstandard accommodations, restaurants, and other tourism services. In addition, the reservoir plays an ecological and biological role as it is a major resting place for migratory birds.

Although the Rozkoš hydraulic structure is in an attractive location and its extensive water surface offers broad opportunities for recreation, this potential is

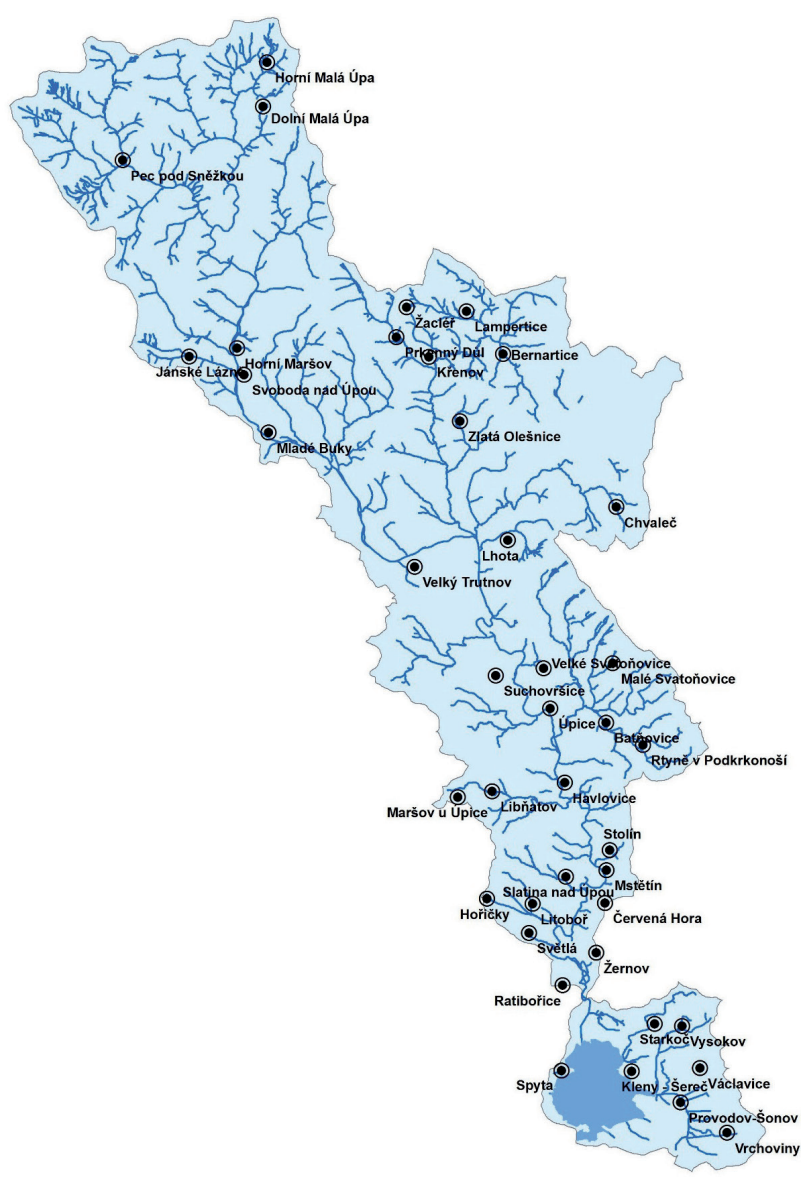

Fig. 1. Simplified map of the Lake Rozkoš watershed. 
currently not adequately used. One of the reasons are excessive blooms of green algae and cyanobacteria, which periodically occur in the reservoir during summer. Due to this quality impairment, the public is warned against entering the water. The main reason for these algae blooms is the large supply of phosphorus from the catchment area, primarily from sewage waters. This process is known as eutrophication.

Therefore, an effective reduction of the discharge of phosphorus from settlements into the reservoir catchment is the only feasible option that will improve the current water quality. Ultimately, this should also cause an increase in interest in recreation in this large water body.

To reduce the significance of eutrophication in areas upstream of reservoirs that have water management or recreational importance, the use of technologies for eliminating phosphorus from municipal wastewater is critical for maintaining water quality. In an ideal case, the wastewater can be transported downstream of the reservoir. Typically, however, various wastewater treatment technologies directly downstream of the municipality are chosen. The simplest technologies based on mere coagulation of phosphorus with various aluminium or ironbased salts have little efficiency in smaller sources. Good results can be achieved using membrane technologies. However, they are very expensive both to build and to operate, and they are cost-ineffective in smaller sources. Thus, an option is needed that will combine and optimise well-known means of achieving noticeable effects while retaining adequate economic efficiency.

To resolve this problem and improve conditions for summer recreation, a comprehensive study [13] has suggested that it is important to focus on the point sources of pollution. The natural background of the forest stands and erosion wash-off are much less important sources of phosphorus pollution. The study identified municipalities or their parts as those where technological adjustments are necessary, also in terms of upgrading existing wastewater treatment plants (WWTPs) or constructing new WWTP.

Two scenarios for achieving the targeted environmental standards in Lake Rozkoš were developed by specialists from Povodí Labe, a state enterprise. All of the solutions are based either on building or upgrading individual municipal WWTPs or on building joint treatment plants for several municipalities. Details of the scenarios analysed are described in Chapter 4.

The problem of WWTP investment program design and space-allocations would be possible to manage via an auction mechanism, where the participants act under information asymmetry. In our paper, we present solutions when the cost assessment information is available to relevant decision-makers. As mentioned in the introduction, the process of optimization is modelled with reverse combinatorial auction theory.

\section{The Optimum Computation Model}

The aim of our paper is to calculate the minimal cost of pollution reduction when complex coalition structures are possible. For this type of problem, the reverse auction model is appropriate. In this paper, a reverse auction of indivisible items with one buyer and several sellers is applied. Suppose that $m$ potential sellers (municipalities in our case) $S_{1}, S_{2}, \ldots, S_{m}$ offer a set $R$ of $r$ items (building water treatment plants), $j=1,2, \ldots, r$, to one buyer $B$ (government in our case); a bid (investment option in our application) made by the seller $S_{h}, h=1,2, \ldots, m$, would be defined as:

$$
b_{h}=\left\{C, c_{h}(C)\right\},
$$

...where $C \subseteq R$ is a combination of items and $c_{h}(C)$ is the price offered by seller $S_{h}$ for the combination of items $C$. The constraints ensure that the procurement provides at least one set of all items. The objective is to minimize the buyer's cost, given the bids made by the sellers. Investment and operation costs are taken into account in this paper.

Binary variables are introduced for the model formulation:

$y_{h}(C)$ is a binary variable specifying whether the combination $C$ is bought from the seller $S_{h}\left(y_{h}(C)=1\right)$.

The basic reverse combinatorial auctions model can be formulated as follows (Cramton et al. 2006):

$$
\sum_{h=1}^{m} c_{h}(C) y_{h}(C) \rightarrow \min
$$

... subject to:

$$
\sum_{h=1}^{m} \sum_{C \subseteq R} y_{h}(C) \geq 1, \forall j \in R,
$$

$$
y_{h}(C) \in\{0,1\}, \forall C \subseteq R, \quad \forall h, h=1,2, \ldots, m .
$$

The standard model is used to find the optimal solution for the purchase of a combination of items. In our problem, the model is used to find the optimal coalition structure of projects in the program. The objective function (1) expresses the desire to minimize costs. The constraints (2) express the requirement that all items (all water-polluting municipalities in our case) are captured. The conditions (3) express binary variables for selecting the item (the municipality) $h$ for the combination of items (the coalition project) $C$.

This basic model considers only the minimization of costs, which is complemented by restrictions on environmental standards. In terms of mathematical formulations, inequalities are added that compare the pollution reduction achieved with the required limit values for five specific environmental parameters (4).

$$
\sum_{h=1}^{m} \sum_{C \subseteq R} e_{h i}(C) y_{h}(C) \geq E_{i}
$$


...where $e_{h i}$ are pollution parameters of the projects and $E_{i}$ are the prescribed environmental standards for the parameters. This is our first step in introducing a multiple quality dimension to the analysis [14].

The model described above provides an optimal coalition structure on the basis of the data that is entered into it. The quality of the computed result is only as good as the quality of the input data. This selection/process can consist of several rounds and makes researchers repeat the model calculations.

The model can theoretically work with various costs - investment costs, net present value of the projects, and various models of annualized costs. Because in this case, the differences in operational costs between the scenarios investigated could be significant, we used average annual costs (AAC), which convert the investment costs to an annual basis. The following formula was used:

$$
A A C=I C * \frac{i(1+i)^{n}}{(1+i)^{n}-1}+O P
$$

...where $A A C$ are the average annual costs, $I C$ are the total investment costs of the project, $i$ is the discount rate, $n$ is the service life of the project, and $O P$ are the average annual operating costs of the project. Because all the projects from a technological point of view were wastewater treatment plants, a uniform service life of $n=15$ was applied to all projects. A discount rate of 5\% (i.e., $i=0.05$ ) was used.

\section{Optimal Solution Computation: Scenarios and Data}

The choice of tactics enabling the removal of phosphorus from municipal wastewater is very important for reducing eutrophication in areas upstream of reservoirs used as drinking water supply or for recreation. In the ideal case, this wastewater can be transported to a larger treatment plant downstream of the reservoir. However, this general method is of little applicability due to the extent of the catchment area of Lake Rozkoš. Nevertheless, it might be a good solution for several municipalities closest to the reservoir, and it is recommended.

However, the currently asserted method of coalition associations is applicable with technologies that assume wastewater treatment directly downstream of single or multiple municipalities. The assessment is made for the two applicable processes (scenario) used for phosphorus removal.

The first scenario assumes the simplest technology based on ordinary coagulation of phosphorus, using various aluminium- or iron-based salts. This coagulation is admittedly effective, but it is very difficult in smaller wastewater sources with uneven inflow to balance the dosage of coagulants so that they remain effective, but are not wasted. Greater sludge volumes have to be expected, and the size of the sludge areas should be adjusted accordingly. The efficiency of phosphorus removal in well-established WWTPs is around $80-85 \%$.
The second scenario can be regarded as highly ecologically efficient, yet very costly. Here, the membrane section is followed by filters with absorbing contents comprised of bentonite or another material with similar properties. The theoretical calculation assumes an $18 \%$ increase of abatement (investment) costs. The efficiency of phosphorus removal may increase to $98-99 \%$.

Although various combinations of the abovementioned technology options will probably be used in reality, it is convenient to assess the two applicable technology options separately in determining the effect of coalition associations.

For modelling the scenarios, a set consisting of 41 individual projects (i.e., a situation where each of the 41 municipalities builds a new or modernises its own

Table 1. Individual wastewater treatment projects.

\begin{tabular}{|c|c|c|c|c|c|}
\hline No. & Code & Municipality & No. & Code & Municipality \\
\hline 1 & M1 & Batňovice & 22 & M22 & Mladé Buky \\
\hline 2 & M2 & Bernartice & 23 & M23 & $\begin{array}{l}\text { Lhota pod } \\
\text { Hořičkami }\end{array}$ \\
\hline 3 & M3 & Křenov & 24 & M24 & Vrchoviny \\
\hline 4 & M4 & Červená Hora & 25 & M25 & $\begin{array}{l}\text { Pec pod } \\
\text { Sněžkou }\end{array}$ \\
\hline 5 & M5 & Mstětín & 26 & M26 & $\begin{array}{l}\text { Provodov- } \\
\text { Šonov }\end{array}$ \\
\hline 6 & M6 & Stolín & 27 & M27 & Kleny-Šeřeč \\
\hline 7 & M7 & Ratibořice & 28 & M28 & Václavice \\
\hline 8 & M8 & Spyta & 29 & M29 & $\begin{array}{c}\text { Rtyně v } \\
\text { Podkrkonoší }\end{array}$ \\
\hline 9 & M9 & Havlovice & 30 & M30 & $\begin{array}{l}\text { Slatina nad } \\
\text { Úpou }\end{array}$ \\
\hline 10 & M10 & Horní Maršov & 31 & M31 & Starkoč \\
\hline 11 & M11 & Hořičky & 32 & M32 & Suchovršice \\
\hline 12 & M12 & Chvaleč & 33 & M33 & $\begin{array}{c}\text { Svoboda nad } \\
\text { Úpou }\end{array}$ \\
\hline 13 & M13 & Janské Lázně & 34 & M34 & Velký Trutnov \\
\hline 14 & M14 & Lampertice & 35 & M35 & Úpice \\
\hline 15 & M15 & Světlá & 36 & M36 & $\begin{array}{c}\text { Velké } \\
\text { Svatoňovice }\end{array}$ \\
\hline 16 & M16 & Libňatov & 37 & M37 & Vysokov \\
\hline 17 & M17 & Litoboř & 38 & M38 & Zlatá Olešnice \\
\hline 18 & M18 & $\begin{array}{l}\text { Horní Malá } \\
\text { Úpa }\end{array}$ & 39 & M39 & Žacléř \\
\hline 19 & M19 & $\begin{array}{l}\text { Dolní Malá } \\
\text { Úpa }\end{array}$ & 40 & M40 & Prkenný Důl \\
\hline 20 & M20 & $\begin{array}{c}\text { Malé } \\
\text { Svatoňovice }\end{array}$ & 41 & M41 & Žernov \\
\hline 21 & M21 & $\begin{array}{l}\text { Maršov u } \\
\text { Úpice }\end{array}$ & & & \\
\hline
\end{tabular}

Note: For the multi-coalitions see Tables 5-8 in the Appendix 
existing wastewater treatment plant) and 125 coalition projects (i.e., situations in which two or more municipalities build common wastewater treatment plants) was created by the experts. When elaborating the table with individual projects (see Table 1), the experts gradually included municipalities in the Lake Rozkoš catchment area from the north to the south, which made it easier to search for potentially effective coalitions (see Tables 2-5 in the Appendix).

Not all of the theoretically possible combinations could be considered. The model is theoretically able to optimize from a huge number of solutions - individual and, especially, coalition projects. In theory, there could be $2^{n}-1$ coalition from $n$ elements, which in reality is an enormous number. In our case of Lake Rozkoš, there are $2^{41}-1$ theoretical coalitions. This number still does not take into account the fact that each, or some, of the projects could have multiple interchangeable options. For instance, one wastewater treatment plant could have alternative locations depending, for instance, on land availability. This limitation was overcome by means of an expert multi-round process of selecting meaningful individual and coalition projects, when the 166 projects mentioned above were selected for the calculations.

\section{Results and Discussion}

\section{Optimal Solution Computation}

The model described in Section 3 was used for computing the optimal (cost-effective) solution for the two scenarios described in Section 4.

\section{Results for Scenario 1}

The computed optimal coalition structure for the first scenario was as follows:

- 14 x 1-coalition: M4, M5, M6, M7, M8, M12, M13, M15, M18, M19, M22, M24, M38, M41.

- 1 x 4-coalition: M30+M17+M11+M23.

- 1 x 5-coalition: M26+M27+M31+M37+M28.

- 2 x 9-coalition: M34+M39+M40+M2+M14+M3+M2 5+M10+M33, M29+M1+M32+M20+M36+M35+M9 $+\mathrm{M} 16+\mathrm{M} 21$.

Total average annual costs of the computed optimal structure are CZK 334.281 million (about $€ 12.4$ million). The average annual costs of the program would be CZK 427.584 million (about $€ 15.9$ million) if all the projects were individual ones. The difference is CZK 93.303 million (about $€ 3.5$ million), which represents a cost savings of about $22 \%$.

\section{Results for Scenario 2}

The computed optimal coalition structure for the third scenario was as follows:

- 12 x 1-coalition: M4, M5, M6, M7, M8, M12, M15, M19, M22, M24, M38, M41.
- 1 x 2-coalition: M13+M18.

- 1 x 4-coalition: M30+M17+M11+M23.

- 1 x 5-coalition: M26+M27+M31+M37+M28.

- 2 x 9-coaliton: M34+M39+M40+M2+M14+M3+M2 5+M10+M33, M29+M1+M32+M20+M36+M35+M9 $+\mathrm{M} 16+\mathrm{M} 21$.

Total average annual costs of the computed optimal structure are CZK 376.102 million (about $€ 14$ million). The average annual costs of the program would be CZK 489.604 million (about $€ 18.1$ million) if all the projects were individual ones. The difference is CZK 113.502 million (about $€ 4.2$ million), which represents a cost savings of about $23 \%$.

\section{Comparison of Scenario Results}

Both scenarios have a very similar structure of coalition projects. The structure in scenario two is the same as in the $2 \times$ 9-coalition, $1 \times$ 4-coalition, and $1 \mathrm{x}$ 5 -coalition projects. In the second scenario, one twocoalition project arises from two individual projects in the optimal structure in the first scenario. Therefore, the number of individual projects (WWTPs) could be reduced in the second scenario.

Concerning the costs, due to using more ecologically efficient and a costlier technology in the second scenario, its AAC are higher by $41.821 \mathrm{mil}$ CZK (€1.55 m), which is approximately $12.5 \%$. This is understood as the marginal costs of the increase of ecological efficiency, when phosphorus is reduced by $98-98 \%$ instead of $80-85 \%$ in the first scenario, i.e., efficiency would increase by more than $19 \%$.

The AAC in the second scenario would be $62.02 \mathrm{~m}$ CZK ( $€ 2.3 \mathrm{~m})$ higher than in the first scenario in case the issues would be solved only via individual projects, which is still very common in the Czech Republic. Considering the coalition projects solution and their optimization in the second scenario results in potential cost savings of $113.502 \mathrm{~m} \mathrm{CZK} \mathrm{(€4.2} \mathrm{m).} \mathrm{If} \mathrm{we} \mathrm{would} \mathrm{reduce}$ this amount by the amount of costs needed for realizing the second scenario via individual projects, we would be left with a "cost pillar" of 113.502-62.02 $=51.482 \mathrm{~m} \mathrm{CZK}$ (€1.9 m).

\section{Results of Sensitivity Analysis}

For further negotiations about the in-practice realized investment program, it is useful to learn how sensitive (in terms of cost differences) deviations from the optimized coalition solution/structure to other feasible structures would be.

Our sensitivity analysis is seen as an exploration of interdependence between costs and coalition structures in designing the WWTPs. The number of feasible coalition structures is huge (in our case, there are $2^{166}$ of them); therefore, it is not possible to analyse all of them.

First, we analysed the solution structures, which follow the computed first best solution. To learn about details of these structures, we computed the second-best, third-best, 
etc. solutions (see Table 2). Generally, we obtained the i-th best solution by solving the problems $(1,2,3)$ and adding one constraint:

$$
\sum_{h=1}^{m} \sum_{C \subseteq R} c_{h}(C) y_{h}(C) \geq A A C_{i-1}+\varepsilon
$$

...where $\varepsilon$ is a small positive value. The costs for the i-best solution are denoted $A A C_{i}$. This procedure is repeated for the other ordered solutions.

Conclusions resulting from the calculations:

- Differences between the costs of subsequent solutions are very small.

- There is a big number of coalitions with almost the same cost.

- All computed structures contain nine coalitions.
- Although the cost differences between subsequent solutions are small, the respective coalition structures are different.

As for previous analyses, due to the high number of feasible coalition structures, they do not provide very useful practical results; we therefore propose sensitivity analysis based on analysing coalition structures for specific cost levels. The difference ("space") between costs for individual projects and costs for the first best solution is divided into several levels corresponding to policy decisions about potential (politically acceptable) deviation of the practical program from the (theoretical) first-best solution. The levels create borders of quintiles in the space of all potential (feasible) solutions. In our case, we simulated a situation where about $20 \%$ of the cost deviation is acceptable. Level 1 is defined as the cost for the first best solution and level 6 as the cost for individual

Table 2. Map of coalition structures following the first best (optimal) solution.

\begin{tabular}{|c|c|c|}
\hline Solution & $\begin{array}{c}\text { Costs } \\
(\mathrm{m} \mathrm{CZK})\end{array}$ & Structure description \\
\hline $1^{\text {st }}$ best solution & 376.102 & $\begin{array}{c}12 \text { x 1-coalition: M4, M5, M6, M7, M8, M12, M15, M19, M22, M24, M38, M41 } \\
1 \text { x 2-coalition: M13+M18 } \\
1 \text { x 4-coalition: M30+M17+M11+M23 } \\
1 \text { x 5-coalition: M26+M27+M31+M37+M28 } \\
2 \text { x 9-coalition: M34+M39+M40+M2+M14+M3+M25+M10+M33, } \\
\text { M29+M1+M32+M20+M36+M35+M9+M16+M21 }\end{array}$ \\
\hline $2^{\text {nd }}$ best solution & 376.262 & $\begin{array}{c}14 \text { x 1-coalition: M4, M5, M6, M7, M8, M12, M15, M19, M22, M24, M27, M28, M38, M41 } \\
1 \text { x 2-coalition: M13+M18 } \\
1 \times 3 \text {-coalition: M31+M37+M28 } \\
1 \text { x 4-coalition: M30+M17+M11+M23 } \\
2 \text { x 9-coalition: M34+M39+M40+M2+M14+M3+M25+M10+M33, } \\
\text { M29+M1+M32+M20+M36+M35+M9+M16+M21 }\end{array}$ \\
\hline $3^{\text {rd }}$ best solution & 376.285 & $\begin{array}{c}13 \text { x 1-coalition: M4, M5, M6, M7, M8, M12, M15, M19, M21, M22, M24, M38, M41 } \\
1 \text { x 2-coalition: M13+M18 } \\
\text { 1 x 4-coalition: M30+M17+M11+M23 } \\
1 \text { x 5-coalition: M26+M27+M31+M37+M28 } \\
1 \text { x 8-coalition: M1+M32+M20+M36+M29+M35+M9+M16 } \\
1 \text { x 9-coalition: M34+M39+M40+M2+M14+M3+M25+M10+M33, }\end{array}$ \\
\hline $4^{\text {th }}$ best solution & 376.406 & $\begin{array}{r}12 \text { x 1-coalition: M4, M5, M6, M7, M8, M12, M15, M19, M22, M24, M38, M41 } \\
1 \text { x 2-coalition: M13+M18 } \\
1 \text { x 4-coalition: M23+M30+M17+M11 (the same as M30+M17+M11+M23 but with different } \\
\text { WWTP location and different costs) } \\
1 \times 5 \text {-coalition: M26+M27+M31+M37+M28 } \\
\text { 2x 9-coalition: M34+M39+M40+M2+M14+M3+M25+M10+M33, } \\
\text { M29+M1+M32+M20+M36+M35+M9+M16+M21 }\end{array}$ \\
\hline $5^{\text {th }}$ best solution & 376.445 & $\begin{array}{c}15 \text { x 1-coalition: M4, M5, M6, M7, M8, M12, M15, M19, M21, M22, M24, M27, M28, M38, } \\
\text { M41 } \\
1 \text { x 2-coalition: M13+M18 } \\
1 \times 3 \text {-coalition: M31+M37+M26 } \\
1 \text { x 4-coalition: M30+M17+M11+M23 } \\
1 \times \text { 8-coalition: M1+M32+M20+M36+ M29+M35+M9+M16 } \\
1 \text { x 9-coaliton: M34+M39+M40+M2+M14+M3+M25+M10+M33, }\end{array}$ \\
\hline $6^{\text {th }}$ best solution & 376.474 & $\begin{array}{r}10 \text { x 1-coalition: M4, M5, M6, M8, M12, M15, M19, M22, M24, M38, } \\
1 \text { x 2-coalition: M13+M18 } \\
1 \text { x 5-coalition: M26+M27+M31+M37+M28 } \\
1 \text { x 6-coalition: M23+M30+M17+M11+M7+M41 } \\
2 \text { x 9-coalition: M34+M39+M40+M2+M14+M3+M25+M10+M33, } \\
\text { M29+M1+M32+M20+M36+M35+M9+M16+M21 }\end{array}$ \\
\hline
\end{tabular}


projects. Other levels are always about 20 percent higher than the previous level, where the second level is the politically acceptable one.

The solutions for the cost levels are computed from the basic model (see formulas 1, 2, and 3) adding a constraint:

$$
\sum_{h=1}^{m} \sum_{C \subseteq R} c_{h}(C) y_{h}(C) \geq L_{i}
$$

...where Li are cost levels, $i=1,2, \ldots, 6$.

The results of the level computation are shown in Table 3 .

In the next step, optimal feasible structures were computed for the six levels (see Table 4).

These calculations provided the following evidence:

- The number of multiple-member coalitions decreases with the increase of cost levels.

- the biggest change in the coalition structure occurred during the transition from the first to the second cost level.

\section{Discussion}

The approach presented in this paper has been certified as a part of an official methodology by the Czech Ministry of Agriculture [15]. This paper describes its second practical application - the case of the recreational lake Rozkoš in the Czech Republic. The results indicate a potential of over $20 \%$ reduction of the abatement costs (calculated as average annual costs) through realization of multiple-coalition projects in contrast to the adoption of a traditional solution, i.e. realization of individual projects only - individual WWTPs for all municipalities.

Although the preliminary results from the Lake Rozkoš case indicate a potential for significant cost savings in the given field of environmental policy, concrete results are determined by the given case, i.e. the cost-effectiveness increase potential must be investigated for every case individually. For instance, computations for the case of the Vrchlice drinking water reservoir (the first practical application of this methodology in the Czech Republic) have shown a potential of cost saving of up to $14 \%$,

Table 3. Level computation results.

\begin{tabular}{|c|c|}
\hline Cost difference in level calculation (m. CZK) & Costs related to levels (m CZK) \\
\hline Cost of individual projects: 489.604 & 1. level: $376.102=$ Cost of $1^{\text {st }}$ best solution \\
Cost of $1^{\text {st }}$ best solution: 376.102 & 2. level: 398.802 \\
Total difference in costs: 113.502 & 3. level: 421.502 \\
Cost difference in levels (quintile borders) & 4. level: 444.202 \\
$113,502 / 5=22,700.4$ & 5. level: 466.902 \\
& 6. level: $489.604=$ Cost of individual projects \\
\hline
\end{tabular}

Table 4. Structures computed for the levels (quintile borders).

\begin{tabular}{|c|c|c|}
\hline Level & $\begin{array}{c}\text { Costs } \\
(\mathrm{m} \mathrm{CZK})\end{array}$ & Structure description \\
\hline 1. level $=1^{\text {st }}$ best solution & 376.102 & For the optimal structure see Table 6 \\
\hline 2. level & 398.802 & $\begin{array}{c}22 \text { x 1-coalition: M3, M4, M5, M6, M7, M8, M9, M12, M15, M16, M17, } \\
\text { M18, M19, M21, M24, M25, M31, M32, M36, M37, M39, M41 } \\
\text { 2 x 3-coalition: M26+M27+M28, M30+M23+M11 } \\
2 \text { x 4-coalition: M14+M38+M2+M40, M1+M20+M29+M35 } \\
\text { 1 x 5-coalition: M34+M10+M33+M22+M13 }\end{array}$ \\
\hline 3. level & 421.502 & $\begin{array}{c}23 \text { x 1-coalition: M1, M3, M4, M5, M6, M7, M8, M9, M11, M12, M13, } \\
\text { M14, M15, M16, M18, M21, M24, M26, M27, M28, M29, M40, M41 } \\
\text { 4x 2-coalition: M10+M19, M35+M20, M31+M37, M32+M36 } \\
\text { 2x 3-coalition: M23+M30+M17, M39+M38+M2 } \\
\text { 1 x 4-coalition: M34+M25+M22+M33 }\end{array}$ \\
\hline 4. level & 444.202 & $\begin{array}{c}\text { 23 x 1-coalition: M1, M4, M5, M6, M7, M8, M9, M11, M12, M14, M15, } \\
\text { M16, M18, M19, M21, M22, M24, M29, M32, M33, M36, M38, M41 } \\
\text { 4x 2-coalition: M34+M25, M13+M10, M35+M20, M31+M37 } \\
\text { 2x 3-coalition: M23+M30+M17, M26+M27+M28 } \\
\text { 1 x 4-coalition: M39+M3+M2+M40 }\end{array}$ \\
\hline 5. level & 466.902 & $\begin{array}{l}22 \text { x 1-coalition: M3, M4, M5, M6, M7, M8, M9, M10, M12, M14, M15, } \\
\text { M16, M17, M18, M19, M21, M24, M25, M31, M34, M37, M41 } \\
\text { 2x 2-coalition: M39+M40, M2+M38 } \\
\text { 5x 3-coalition: M13+M33+M22, M29+M1+M35, M26+M27+M28, } \\
\text { M30+M23+M11, M20+M36+M32 }\end{array}$ \\
\hline 6. level $=$ individual projects solution & 489.604 & 41x 1-coalition: M1 - M41 \\
\hline
\end{tabular}


depending on the scenario formulation (for details see [16]).

Existing applications of the approach have shown its usefulness for the support of decision-making in management of water quality in practice. When negotiating the realization details of plans for water quality improvement in lakes and river basins, it is possible to compare solutions resulting from the negotiations of (concrete) stakeholders with the results of the optimization computations [17-20]. In cases where the differences are not too big (such as the politically acceptable deviation of up-to $20 \%$ cost increase in our case), a negotiated solution different from the optimal one could be accepted. The reason for accepting such differences could be, for instance, aversion of some municipalities to mutually collaborate "on anything", when the time postponement of the situation solution means significant social costs. Also, so-called "soft effects" could be a reason for accepting more costly solutions. For instance, experts from the Elbe river basin management mentioned that building common and thus larger WWTPs create the possibility to employ higher educated and experienced WWTP operating staff (pers. communication). This, in turn, creates potential for better care of the technologies compared to situations when WWTPs are operated by less competent staff, with higher levels of fluctuations and lower salaries. Also, it will be cheaper to install modernized technologies to less facilities in the future.

It is important to note that the auctions described herein are merely simulated using a computer model; the purpose is to identify optimal solutions, and their real-world implementation is not necessary since all the information is available to the regulating authority. Real-world reverse combinatorial auctions would need to be carried out in a situation of information asymmetry, where entities make obvious their actual abatement costs only by means of bidding and do not make them available otherwise [18, 19]. Such a situation would be quite common where polluters request support from public budgets $[21,22,10]$. Auctions that are not simulated have only been tested in laboratory experiments so far; yet, we believe that their results are quite promising [17].

In the case of the water reservoir analysed by us, virtually the only sources of phosphorus (and other) pollution were point sources, specifically pollution originating from municipalities of various sizes. In other cases, areal sources, particularly agricultural farms, are usually additional major sources of pollution. This is an important issue, because unlike municipalities, they are private companies and so require a different management approach. Expert estimates of abatement costs can be made for them as well. However, unlike with municipalities, the practical solutions will be frequently difficult negotiations under an information asymmetry as outlined above. There is also a rich body of literature on solving the problem of reducing water pollution from agriculture Schoumans [24] provides a comprehensive review of mitigation techniques available for focusing on the diffuse pollution cause by agriculture. Melland [25] studies the connection between types of farms, underlying factors like soil and the pollution. Finally, Sharpley [26] explores the dynamics of these improvements, taking into account the effects of legacy phosphorus.

As noted above, our exercise represents the costeffectiveness problem/viewpoint. It is a well-known fact that construction of WWTP in small municipalities is relatively costly and usually not feasible without a contribution from the public budgets. There is a wealth of literature indicating that the economic benefits of removing pollution from reservoirs may be relatively high. Among international literature, let us mention three papers that mostly constitute a literature review mapping the effort of scholars over several past decades. Thirty studies published in the period 1971-1997 are analysed in [27]. Long-term interest in economic analyses of clean waters is shown in [28]. Among more recent world literature shedding light on assessment of ecosystem services, including the value of improved water quality, we can quote $[29,30]$.

As for the Central and Eastern European region, research at Mácha Lake in the Czech Republic [31] has shown tourists' willingness to pay 13 euros a person a day for cleaner water, providing that the water is so clean that it allows swimming, and another 4 euros a person a day if the water is crystal clear. Another study elaborated for Legowskie Lake in Poland and Mácha Lake in the Czech Republic $[32,33]$ also pointed out the significant economic value of water reservoirs and quality of the water in them.

Our study also has makes a theoretical contribution. An auction is a market mechanism, which that generally does not need to sell or buy all of the auctioned items. Using The use of auctions ranges from a sale of art objects, through a sale of flowers, to allocations of radio spectrumfrequencies and, a sale of electricity to state purchases or sales power utilities [34-36]. For example, auctions of spectrum radio frequency rights could may not always generate sufficient revenue due to errors in the auction design of the auction, especially the lack of appreciation of the role of auctions in creating incentives for entry and prevent collusive agreements [37]. Our paper and the case study seek to enrich the theory of reverse combinatorial auctions, where buyers are trying try to buy all the offered items at the lowest cost. The area of application of the model of reverse combinatorial auctions on to the environment where an environmental authority buys projects to reduce pollution is another contribution of our research.

\section{Conclusions}

The approach highlighted the significant potential for optimisation leading to reduced costs of solutions to water eutrophication in a water reservoir when implementing joint municipal WWTPs compared to implementation of an individual WWTP for each municipalities.

The case study was implemented in a situation where virtually all the pollution in the reservoir originates from 
point sources of pollution - municipalities. The problem will have to be extended by including aerial sources farms, which are a major source in some cases.

Even the first cases where the optimisation has been tested show that the approach is applicable in practice for support to decision-making, both in cases where the calculation result is used directly to draw cost-effective alternatives of the design to reduce $\mathrm{P}$ in an area/water reservoir, and in situations where actors negotiate about a joint project to gain support from public budgets. In such cases, the design proposed can be compared to the estimated effective solution.

We believe that the presented approach can serve as a useful support for increasing the cost-effectiveness of allocation of both national and EU financial resources dedicated to increasing water quality in river basins and lakes.

\section{Acknowledgements}

The paper was developed with the support of the Czech Science Foundation, GACR No. 16-01687S: "Novel approach to seeking cost/effective water pollution abatement: Developing reverse combinatorial auctions theory". Thanks go to Luděk Rederer and Petr Ferbar from the state enterprise Povodí Labe for their useful feedback and for providing data and other materials about the case of Lake Rozkoš. The cost data estimates used in the computations are available from the authors.

\section{Appendix}

Table 5. Duo-coalition projects.

\begin{tabular}{|c|c|c|c|}
\hline No. & Code & \multicolumn{2}{|c|}{ Municipalities in coalition } \\
\hline 1 & M34M38 & Velký Trutnov & Zlatá Olešnice \\
\hline 2 & M34M33 & Velký Trutnov & Svoboda nad Úpou \\
\hline 3 & M34M25 & Velký Trutnov & Pec pod Sněžkou \\
\hline 4 & M34M39 & Velký Trutnov & Žaclér̆ \\
\hline 5 & M34M40 & Velký Trutnov & Prkenný Důl \\
\hline 6 & M34M10 & Velký Trutnov & Horní Maršov \\
\hline 7 & M34M18 & Velký Trutnov & Horni Malá Úpa \\
\hline 8 & M34M19 & Velký Trutnov & Dolní Malá Úpa \\
\hline 9 & M34M2 & Velký Trutnov & Bernartice \\
\hline 10 & M34M12 & Velký Trutnov & Chvaleč \\
\hline 11 & M13M25 & Janské Lázně & Pec pod Sněžkou \\
\hline 12 & M13M33 & Janské Lázně & Svoboda nad Úpou \\
\hline 13 & M13M10 & Janské Lázně & Horní Maršov \\
\hline 14 & M13M18 & Janské Lázně & Horní Malá Úpa \\
\hline 15 & M13M19 & Janské Lázně & Dolní Malá Úpa \\
\hline 16 & M10M14 & Horni Maršov & Lampertice \\
\hline 17 & M10M33 & Horní Maršov & Svoboda nad Úpou \\
\hline 18 & M10M19 & Horní Maršov & Dolní Malá Úpa \\
\hline 19 & M10M39 & Horní Maršov & Žacléŕ \\
\hline 20 & M26M27 & Provodov-Šonov & Kleny-Šeřeč \\
\hline 21 & M26M28 & Provodov-Šonov & Václavice \\
\hline 22 & M26M23 & Provodov-Šonov & Lhota pod Hořičkami \\
\hline 23 & M39M14 & Žacléř & Lampertice \\
\hline 24 & M39M40 & Žacléř & Prkenný Důl \\
\hline 25 & M39M38 & Žacléŕ & Zlatá Olešnice \\
\hline 26 & M2M39 & Bernartice & Žacléŕ \\
\hline 27 & M2M38 & Bernartice & Zlatá Olešnice \\
\hline 28 & M20M36 & $\begin{array}{c}\text { Malé } \\
\text { Svatoňovice }\end{array}$ & Velké Svatoňovice \\
\hline 29 & M20M29 & $\begin{array}{c}\text { Malé } \\
\text { Svatoňovice }\end{array}$ & Rtyně v Podkrkonoší \\
\hline 30 & M35M21 & Úpice & Maršov u Úpice \\
\hline 31 & M35M36 & Úpice & Velké Svatoňovice \\
\hline 32 & M35M20 & Úpice & Malé Svatoňovice \\
\hline 33 & M31M37 & Starkoč & Vysokov \\
\hline 34 & M32M36 & Suchovršice & Velké Svatoňovice \\
\hline 35 & M22M33 & Mladé Buky & Svoboda nad Úpou \\
\hline
\end{tabular}


Table 6. Trio-coalition projects.

\begin{tabular}{|c|c|c|c|c|}
\hline No. & Code & \multicolumn{3}{|c|}{ Municipalities in coalition } \\
\hline 1 & M34M38M22 & Velký Trutnov & Zlatá Olešnice & Mladé Buky \\
\hline 2 & M34M33M10 & Velký Trutnov & Svoboda nad Úpou & Horní Maršov \\
\hline 3 & M34M25M10 & Velký Trutnov & Pec pod Sněžkou & Horní Maršov \\
\hline 4 & M34M39M14 & Velký Trutnov & Žacléř & Lampertice \\
\hline 5 & M34M40M39 & Velký Trutnov & Prkenný Důl & Žacléŕ \\
\hline 6 & M34M10M18 & Velký Trutnov & Horní Maršov & Horní Malá Úpa \\
\hline 7 & M34M18M19 & Velký Trutnov & Horní Malá Úpa & Dolní Malá Úpa \\
\hline 8 & M34M19M13 & Velký Trutnov & Dolní Malá Úpa & Janské Lázně \\
\hline 9 & M34M2M3 & Velký Trutnov & Bernartice & Křenov \\
\hline 10 & M34M12M2 & Velký Trutnov & Chvaleč & Bernartice \\
\hline 11 & M13M25M10 & Janské Lázně & Pec pod Sněžkou & Horní Maršov \\
\hline 12 & M13M33M22 & Janské Lázně & Svoboda nad Úpou & Mladé Buky \\
\hline 13 & M29M1M35 & Rtyně v Podkrkonoší & Batňovice & Úpice \\
\hline 14 & M29M1M32 & Rtyně v Podkrkonoší & Batňovice & Suchovršice \\
\hline 15 & M29M9M32 & Rtyně v Podkrkonoší & Havlovice & Suchovršice \\
\hline 16 & M29M9M20 & Rtyně v Podkrkonoší & Havlovice & Malé Svatoňovice \\
\hline 17 & M23M30M17 & Lhota pod Hořičkami & Slatina nad Úpou & Litobor̆ \\
\hline 18 & M23M7M17 & Lhota pod Hořičkami & Ratibořice & Litoboř \\
\hline 19 & M23M7M41 & Lhota pod Hořičkami & Ratibořice & Žernov \\
\hline 20 & M26M27M31 & Provodov-Šonov & Kleny- Šeřeč & Starkoč \\
\hline 21 & M26M28M31 & Provodov-Šonov & Václavice & Starkoč \\
\hline 22 & M26M27M28 & Provodov-Šonov & Kleny- Šeřeč & Václavice \\
\hline 23 & M39M14M2 & Žacléŕ & Lampertice & Bernartice \\
\hline 24 & M39M40M22 & Žacléŕ & Prkenný Důl & Mladé Buky \\
\hline 25 & M39M38M2 & Žacléŕ & Zlatá Olešnice & Bernartice \\
\hline 26 & M39M2M40 & Žacléŕ & Bernartice & Prkenný Důl \\
\hline 27 & M2M38M14 & Bernartice & Zlatá Olešnice & Lampertice \\
\hline 28 & M20M36M32 & Malé Svatoňovice & Velké Svatoňovice & Suchovršice \\
\hline 29 & M20M29M36 & Malé Svatoňovice & Rtyně v Podkrkonoší & Velké Svatoňovice \\
\hline 30 & M30M16M11 & Slatina nad Úpou & Libňatov & Hořičky \\
\hline 31 & M30M23M11 & Slatina nad Úpou & Lhota pod Hořičkami & Hořičky \\
\hline 32 & M35M20M1 & Úpice & Malé Svatoňovice & Batňovice \\
\hline 33 & M31M37M26 & Starkoč & Vysokov & Provodov-Šonov \\
\hline 34 & M32M36M35 & Suchovršice & Velké Svatoňovice & Úpice \\
\hline 35 & M22M33M34 & Mladé Buky & Svoboda nad Úpou & Velký Trutnov \\
\hline
\end{tabular}


Table 7. Four-coalition projects.

\begin{tabular}{|c|c|c|c|c|c|}
\hline No. & Code & \multicolumn{4}{|c|}{ Municipalities in coalition } \\
\hline 1 & M34M38M22M3 & Velký Trutnov & Zlatá Olešnice & Mladé Buky & Křenov \\
\hline 2 & M34M33M10M22 & Velký Trutnov & Svoboda nad Úpou & Horní Maršov & Mladé Buky \\
\hline 3 & M34M25M10M33 & Velký Trutnov & Pec pod Sněžkou & Horní Maršov & Svoboda nad Úpou \\
\hline 4 & M34M39M14M2 & Velký Trutnov & Žacléŕ & Lampertice & Bernartice \\
\hline 5 & M34M39M40M2 & Velký Trutnov & Žacléř & Prkenný Důl & Bernartice \\
\hline 6 & M34M25M18M10 & Velký Trutnov & Pec pod Sněžkou & Horní Malá Úpa & Horní Maršov \\
\hline 7 & M34M18M19M10 & Velký Trutnov & Horní Malá Úpa & Dolní Malá Úpa & Horní Maršov \\
\hline 8 & M34M19M13M18 & Velký Trutnov & Dolní Malá Úpa & Janské Lázně & Horní Malá Úpa \\
\hline 9 & M34M2M3M38 & Velký Trutnov & Bernartice & Křenov & Zlatá Olešnice \\
\hline 10 & M34M2M12M38 & Velký Trutnov & Bernartice & Chvaleč & Zlatá Olešnice \\
\hline 11 & M34M25M13M10 & Velký Trutnov & Pec pod Sněžkou & Janské Lázně & Horní Maršov \\
\hline 12 & M13M33M22M10 & Janské Lázně & Svoboda nad Úpou & Mladé Buky & Horní Maršov \\
\hline 13 & M29M1M32M35 & Rtyně v Podkrkonoší & Batňovice & Suchovršice & Úpice \\
\hline 14 & M29M1M32M20 & Rtyně v Podkrkonoší & Batňovice & Suchovršice & Malé Svatoňovice \\
\hline 15 & M29M9M32M35 & Rtyně v Podkrkonoší & Havlovice & Suchovršice & Úpice \\
\hline 16 & M29M9M20M35 & Rtyně v Podkrkonoší & Havlovice & Malé Svatoňovice & Úpice \\
\hline 17 & M23M30M17M11 & Lhota pod Hořičkami & Slatina nad Úpou & Litoboř & Hořičky \\
\hline 18 & M23M7M17M11 & Lhota pod Hořičkami & Ratibořice & Litoboř & Hořičky \\
\hline 19 & M23M7M41M30 & Lhota pod Hořičkami & Ratibořice & Žernov & Slatina nad Úpou \\
\hline 20 & M23M11M31M4 & Lhota pod Hořičkami & Hořičky & Starkoč & Červená Hora \\
\hline 21 & M26M27M31M28 & Provodov-Šonov & Kleny - Šeřeč & Starkoč & Václavice \\
\hline 22 & M26M27M31M37 & Provodov-Šonov & Kleny - Šeřeč & Starkoč & Vysokov \\
\hline 23 & M39M14M2M38 & Žacléř & Lampertice & Bernartice & Zlatá Olešnice \\
\hline 24 & M39M40M22M33 & Žacléŕ & Prkenný Důl & Mladé Buky & Svoboda nad Úpou \\
\hline 25 & M39M3M2M38 & Žacléř & Křenov & Bernartice & Zlatá Olešnice \\
\hline 26 & M39M3M2M40 & Žaclér̆ & Křenov & Bernartice & Prkenný Důl \\
\hline 27 & M14M38M2M40 & Lampertice & Zlatá Olešnice & Bernartice & Prkenný Důl \\
\hline 28 & M20M36M32M35 & Malé Svatoňovice & Velké Svatoňovice & Suchovršice & Úpice \\
\hline 29 & M20M36M29M35 & Malé Svatoňovice & Velké Svatoňovice & $\begin{array}{c}\text { Rtyně v } \\
\text { Podkrkonoší }\end{array}$ & Úpice \\
\hline 30 & M30M16M11M23 & Slatina nad Úpou & Libñatov & Hořičky & Lhota pod Hořičkami \\
\hline 31 & M30M17M11M23 & Slatina nad Úpou & Litoboř & Hořičky & Lhota pod Hořičkami \\
\hline 32 & M1M20M29M35 & Batňovice & Malé Svatoňovice & $\begin{array}{c}\text { Rtyně v } \\
\text { Podkrkonoší }\end{array}$ & Úpice \\
\hline 33 & M26M28M31M37 & Provodov-Šonov & Václavice & Starkoč & Vysokov \\
\hline 34 & M1M36M32M35 & Batňovice & Velké Svatoňovice & Suchovršice & Úpice \\
\hline 35 & M34M25M22M33 & Velký Trutnov & Pec pod Sněžkou & Mladé Buky & Svoboda nad Úpou \\
\hline
\end{tabular}




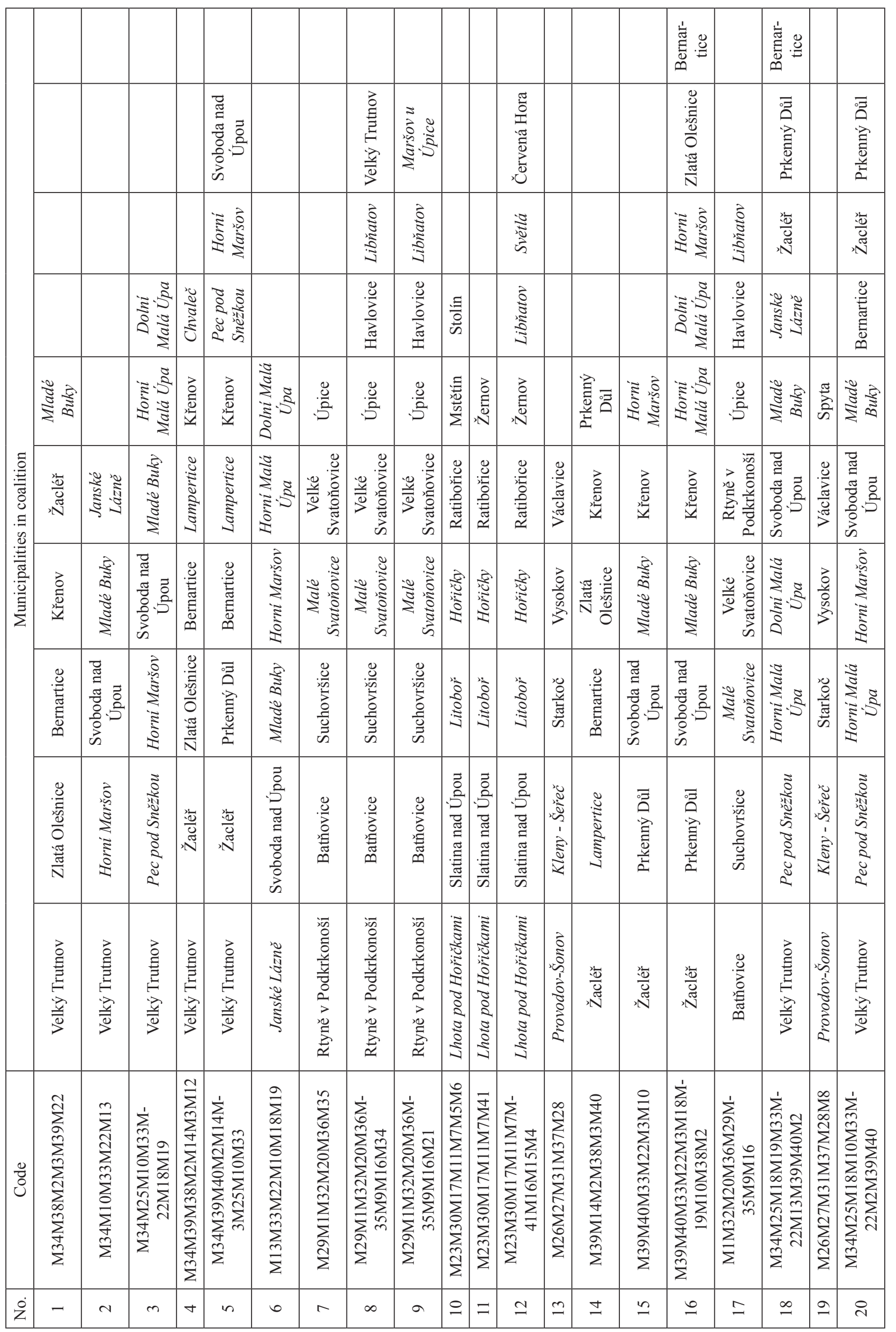




\section{References}

1. Directive 2000/60/EC of the European Parliament and of the Council of 23 October 2000 establishing a framework for Community action in the field of water policy, 2000.

2. PEREZ M. A New Strategy to Improve Water Quality-One Targeted Watershed at a Time, World Resource Institute, 2014, available at: http://www.wri.org/blog/new-strategy-improve-water-quality $\% \mathrm{E} 2 \% 80 \% 94$ one-targeted-watershedtime?utm_campaign $=$ socialmedia\&utm source $=$ facebook. com\&utm_medium=wri-page, approached January 8, 2014

3. WALEGA A., KOWALIK T., BOGDAL A. Estimating the Occurrence of Trends in Selected Elements of a Small SubMountain Catchment Hydrological Regime, Pol. J. Environ. Stud. 22 (5), 2151, 2016.

4. HAJKOWICZ S., COLLINS K. A review of multiple criteria analysis for water resource planning and management, Water Resour Manag 21 (9), 1553, 2007.

5. REVELLE C., DIETRICH G., STENSEL D. The improvement of water quality under a financial constraint: a commentary on 'linear programming applied to water quality management'. Water Resour Res 5 (2), 507, 1969.

6. LEE C.S., WEN C.G. 1997 Fuzzy goal programming approach for water quality management in a river basin. Fuzzy Sets and Systems 89 (2), 181, 1997.

7. HUANG G.H., LOUCKS D.P. An inexact two-stages stochastic programming model for water resources management under uncertainty. Civil Engineering and Environmental Systems 17 (2), 95, 2000.

8. de VRIES S., VOHRA R.V. Combinatorial auctions: a survey. INFORMS J Comput 15 (1), 284, 2003.

9. CRAMTON P., SHOHAM Y., STEINBERG R (eds.). Combinatorial Auctions, MIT Press, Cambridge, 2006.

10. FIALA P., ŠAUER P. Application of Combinatorial Auctions on Allocation of Public Financial Support in the Area of Environmental Protection: Economic Laboratory Experiment. Politická ekonomie, 59 (3), 379, 2011.

11. PL. Limnological dindings and possibilities to improve current condition in the Lake Rozkoš [in Czech], Povodí Labe, s.p., Hradec Králové, 1999.

12. PL. Control order at the waterwork Rozkoš [in Czech], Povodí Labe, s.p., Hradec Králové, 2007.

13. VRV/PL. An Analysis of Importance of Impact of Eutrophication Pollution Sources at the River Basin of Water Lake Rozkoš [in Czech], Vodohospodářský rozvoj a výstavba a.s. nad Povodí Labe, s.p., Praha, 2013.

14. GENKENBACH M.F., WEIKARD H.P. Modelling the urban water chain: incentives and cost recovery in wastewater treatment in developing countries. Urban Water J 9 (3), 149, 2012.

15. MoA. Methodology for economic and environmental optimization of reducing pollution in watercourses, Ministry of Agriculture, certificate no. 79469/2013-MZe, Prague, 2013 [In Czech].

16. ŠAUER P., FIALA P., DVOŘÁK A., KOLÍNSKÝ O. Coalition Projects in Wastewater Treatment: The Case of a Drinking Water Reservoir in the Czech Republic. J. Environ. Prot. Ecol. 16 (4), 1492, 2015.

17. ŠAUER P., FIALA P., DVOŘÁK A., KOLÍNSKÝ O., PRÁŠEK J., FERBAR P., REDERER L. Improving quality of surface waters with coalition projects and environmental subsidy negotiation. Pol. J. Environ. Stud 24 (3), 1299, 2015.

18. CARRARO C., MARCHIORI C., SGOBBI A. Negotiating on water: insights from non-cooperative bargaining theory. Environ Dev Econ 12 (2), 329, 2007.
19. MADANI K. Game theory and water resources. Journal of Hydrology, 381 (3), 225, 2010.

20. SLAVIKOVA L., JILKOVA J. Implementing the public participation principle into water management in the Czech Republic: a critical analysis. Regional Studies 45 (4), 545, 2011.

21. SAUER P., DVORAK A., FIALA P. Negotiation between Authority and Polluters - Model for Support of Decision Making in Environmental Policy. Politická Ekonomie, 46 (6), 772, 1998.

22. SAUER P., DVORAK A., FIALA P. A Procedure for Negotiating Pollution Reduction under Information Asymmetry: Surface Water Quality Case. Environ Resour Econ, 24 (2), 103, 2003.

23. DANULETIU D.C., TAMAS-SZORA A., SOCOL A. Affordability and Sustainability of Water Services Investments Financed by EU Funds. J Environ Prot Ecol, 16 (1), 154, 2015.

24. SCHOUMANS O.F., CHARDON W.J., BECHMANN M.E., GASCUEL-ODOUX C., HOFMAN G., KRONVANG B., RUBAEK G.H., ULEN B., DORIOZ J.M. Mitigation options to reduce phosphorus losses from the agricultural sector and improve surface water quality: A review. Science of The Total Environment, 468-469, 1255, 2014.

25. MELLAND A.R., MELLANDER P.E., MURPHY P.N.C., WALL D.P., MECHAN S, SHINE O., SHORTLE G., JORDAN P. Stream water quality in intensive cereal cropping catchments with regulated nutrient management. Environmental Science \& Policy, 24, 58, 2012.

26. SHARPLEYA., JARVIE H.P., BUDAA., MAY L., SPEARS B., KLEINMAN P. Phosphorus legacy: Overcoming the effects of past management practices to mitigate future water quality impairment. Journal of Environmental Quality, $\mathbf{4 2}$ (5), 1308, 2013.

27. WILSON M.A., CARPENTER S.R. Economic Valuation of Freshwater Ecosystem Services in the United States: 19711997, Ecological Applications 9 (3), 772, 1999.

28. CARSON R.T., MARTIN K.M. (1991). Measuring the benefits of freshwater quality changes: Techniques and empirical findings. In DINAR A., ZILBERMAN D. (eds.) The Economics and Management of Water and Drainage in Agriculture, 389-410. Springer US, 1991.

29. BRAUMAN K.A., DAILY G.C., DUARTE T.K.E., MOONEY H.A. The nature and value of ecosystem services: an overview highlighting hydrologic services. Annu. Rev. Environ. Resour. 32, 67, 2007.

30. FISHER B., TURNER K., ZYLSTRA M., BROUWER R., de GROOT R., FARBER S., FERRARO P., GREEN R., HADLEY D., HARLOW J., JEFFERIS P., KIRKBY C., MORLING P., MOWATT S., NAIDOO R., PAAVOLA J., STRASSBURG B., YU D., BALMFORD A. Ecosystem Services and Economic Theory: Integration for Policy -Relevant Research. Ecological applications, 18 (8), 2050. 2008.

31. VOJÁČEK O., PECÁKOVÁ I.: Comparison of Discrete Choice Models for Economic Environmental Research, Prague Economic Papers, 19 (1), 35, 2010.

32. CZAJKOWSKI M., MARKOWSKA A., MARKIEWICZ O., BARTCZAK A., SCASNY M., MELICHAR J., SKOPKOVA H. Lake Water Quality Valuation - Benefit Transfer Approach vs. Empirical Evidence. Ekonomia journal 19 (1), 156-193, available at: http://ekonomia.wne.uw.edu.pl/ekonomia/getFile/652 2007, approached November 2, 2016, 2007.

33. CZAJKOWSKI M., ŠČASNÝ M. Study on benefit transfer in an international setting. How to improve welfare estimates 
in the case of the countries' income heterogeneity? Ecological Economics 69 (12), 2409, 2010.

34. KLEMPERER P. Auctions: Theory and Practice. Princeton Univesity Press, Princeton, 2004.

35. KRISHNA V. Auction Theory. Academic Press, San Diego, 2002.
36. MILGROM P. Putting Auction theory to Work. Cambridge University Press. Cambridge, 2004.

37. KLEMPERER P. How (not) to run auctions: the European 3G Telecom auctions. European Economic Review, 46 (4-5), 829, 2002. 